DOI: 10.34015/2523-4552.2020.3.12

УдК 343.9

Ягунов Д. В., заслужений юрист Украӥни, кандидат наук з державного управління, доцент, MSSc in Criminal Justice e-mail: d.yagunov@gmail.com ORCID: 0000-0002-2822-2268

\title{
SEX OFFENDERS У ПОЛІТИЦІ СОЦІАЛЬНОГО КОНТРОЛЮ: ДО ПИТАННЯ ПРО РЕАКТУАЛІЗАЦІЮ КОНЦЕПЦІЇ НЕБЕЗПЕЧНОГО СТАНУ ОСОБИ
}

Стаття присвячена дослідженню сучасних тенденцій політики соціального контролю у західних країнах, спрямованих на убезпечення суспільства від сексуального насильства. Стаття містить аналіз політичних трансформацій - від «кримінального права свободи» до «кримінального права ризиків».

Ключові слова: політика соціального контролю; позитивістська школа; небезпечний стан особи; сексуальне насильство; пенітенціарна система; безпека суспільства.

Статья посвящена исследованию современных тенденций политики социального контроля в западных странах, направленных на обеспечение безопасности общества от сексуального насилия. Статья содержит анализ политических трансформаций - от «уголовного права свободы» к «уголовному праву рисков».

Ключевые слова: политика социального контроля; позитивистская школа, опасное состояние личности; сексуальное насилие; пенитенциарная система; безопасность общества.

Актуальність цього дослідження обумовлена тим, що у новій системі координат суспільства Постмодерну більш ніж суттєво, занадто та явно розширюється (здебільшого у штучний спосіб) коло девіантів за рахунок збільшення потенційних (іноді навіть просто задекларованих) проявів злочинної поведінки, де ключовими категоріями захисту суспільства стають не «злочин» та «справедливе покарання».

Натомість такими категоріями стали «ризик» та «убезпечення сус- пільства», де дедалі більш глибокий та проникливий соціальний контроль здійснюється над значно більшими групами населення за допомогою різних елементів системи юстиції (включаючи тотальні інституції) у кооперації з неінституційними додатками до системи кримінальної юстиції, засобами масової інформації та транснаціональними приватними акторами.

Постановка проблеми цієї статті обумовлена тим, що сьогодні спостерігається фактичне повернен- 
ня до позитивістської школи 3 її ключової категорією небезпечного стану особи. Спостерігається відродження концепції соціального захисту, основи якої було сформульовано ще у XIX столітті представниками зазначеної школи (Ч. Ломброзо, Е. Феррі, Р. Гарофало, Д. Дріль).

Представники позитивізму зазвичай ставили за мету не зниження застосування покарання, чим характеризувалася класична школа, а зниження концентрації злочинності [1, с. 10]. Відповідно, вчинення злочину позитивісти здебільшого розглядали як прояв pericolosita - тобто небезпечного стану особи.

Злочинець, на відміну від класичного підходу, не розглядався як раціональний актор, а його злочин як прояв його вільного вибору. Як зазначав один із фундаторів позитивістської школи Р. Гарофало, «уся плутанина у питанні осудності грунтується на тому, що автори наших кодексів, відповідно до старої традиції, засновують відповідальність на понятті свободи волі та, як наслідок, понятті можливості свободи вибору» [2, с. 609]. Як наслідок, класичні погляди щодо кримінальної відповідальності, що грунтувалися на карі та кримінально-правовому залякуванні, у такому разі не спрацьовували: «Доктрина Ломброзо хоче зруйнувати кримінальний кодекс та підкопатися під свободу [волі]» [3].

Е. Феррі наступним чином сформулював недоліки класичної школи: «Помилкова шкала моральної відповідальності; абсолютне ігнорування психотипів злочинців; відторгнення ідеї умовного прощення; нульовий практичний ефект ув'язнення як покарання внаслідок корупції та відповідних злочинних асоціацій у в'язницях; мільйони осіб, засуджених до коротких строків позбавлення волі; як наслідок - високі показники рецидивізму» [4, с. 201].

Біологічні та анатомічні моменти, які так ретельно висвітлювалися позитивістами, мало цікавлять сучасну пенітенціарну політику. Тому М. Даббер особливо наголошує на ре-актуалізації у кінці XX століття поглядів 1930-х років: «У сучасному управлінні системою кримінальної юстиції поняття винуватості є недоречним. Оскільки почуття провини більше не мають значення, «засоби захисту», засновані на відсутності свободи волі, застаріли та більше не потребують вивчення. Завданням кримінального процесу вже $\epsilon$ не відокремлення винного від невинного, а виявлення тих, хто має небезпечні та специфічні особливості» [5, c. 53].

Тому, обгрунтовуючи актуальність нашого дослідження, можна особливо підкреслити: у XXI столітті позитивістські погляди стали ще більш актуальними, що підтверджується численними прикладами 3 практики функціонування національних систем кримінальної юстиції.

Причому найбільш яскравим проявом сучасних позитивістських тенденцій $є$ соціальний контроль над девіантами, які вчинили статеві злочини або, краще сказати, «демонструють ризики» вчинення статевих злочинів, які для зручності ми у цій статті будемо умовно визначати як «sex offenders». Адже саме sex offenders, як слушно зазначає М. Вольф, $є$ сьогоднішніми «folk devils» [6].

Виклад основного матеріалу. Передусім, необхідно звернути увагу на соціально-економічні передумови 
такої моральної паніки щодо «загроз» з боку sex offenders.

Перші десятиліття «Холодної війни» на фоні безмежної сексуальної свободи ознаменувалося посиленням регулювання статевих відносин та жорсткістю гендерних норм, а також супутньою популярністю «sexual deviant» - персонажа, побудованого на основі психіатричних та психологічних уявлень про сексуальну поведінку, і якого широко сприймали як загрозу як особистій, так і політичній безпеці та стабільності. Кримінальне законодавство щодо сексуальних психопатів початку другої половини $\mathrm{XX}$ століття являло собою вершину позитивістської тенденції, апогей столітнього руху від відплати злочинцю (retribution) та реформації злочинця (reformation), від класичної до позитивістської кримінології, від класичного покарання до лікування злочинців.

Е. Шен'єр наступним чином розкриває зазначену проблематику: 1940-і роки широко розглядаються як період кардинальних змін у Канаді та США: відсутність чоловіків, розширення економічної незалежності жінок за рахунок оплачуваної зайнятості та зростання кількості спільнот геїв та лесбіянок у військових інституціях та поза ними упродовж першої половини десятиліття. Розширення сексуальної свободи супроводжувалося моральною панікою щодо загроз національної безпеки. Проте головним було те, що на фоні свободи сексуальних відносин мораль стала заповнювати науку, що призвело до більшого нормативного регулювання сексуальних відносин [7, с. 3].

Можна стверджувати, що така популяризація сексуальних девіантів була відображенням політичного проекту розширення сексуальної свободи з одночасним насадженням в суспільстві безмежних дисциплінарно-контрольних механізмів, де дуже слушною здається думка Дж. Оруелла, що «статевий потяг був небезпечний для партії, і партія поставила його собі на службу» [8, c. 119]. Причому ця тенденція кореспондує дисциплінарному концепту М. Фуко: ті самі дисциплінарні мережі, «експерти», «іспити» та ранги. Саме той розподіл індивідів у просTopi.

Е. Сазерленд наступним чином сформулював стереотипи, що вплинули на формування проблеми сексуального насильства в американському суспільстві середини XX століття: 1) жінки та діти перебувають у небезпеці, оскільки тяжкі сексуальні злочини дуже поширені та зростають швидше, ніж будь-який інший вид злочинності; 2) практично всі серйозні статеві злочини вчиняються «дегенератами», «сексуальними дияволами» або «сексуальними психопатами»; 3) ці «сексуальні психопати» продовжують вчиняти серйозні статеві злочини упродовж усього життя, оскільки не мають контролю над своїми сексуальними спонуканнями; вони страждають на психіку та не несуть відповідальності за свою поведінку; 4) сексуального психопата можна 3 високою ймовірністю визначити ще до того, як він вчинив будь-які статеві злочини; 5) суспільство, яке карає сексуальних злочинців навіть суворими покараннями, а потім звільняє їх знову полювати на жінок і дітей, не виконує своїх обов'язків; 6) повинні бути прийняті закони про сегрегацію таких осіб - бажано до, але щонайменше після вчинення ними сексуальних 
злочинів - та про утримання їх як безвідповідальних пацієнтів, поки їхня хвороба не буде повністю й остаточно вилікувана; 7) оскільки сексуальна психопатія - це психічна хвороба, професіональні поради щодо встановлення діагнозу, лікування та звільнення пацієнтів у разі вилікування повинні надходити виключно від психіатрів» $[9$, с. 543-544].

3 цього приводу канадський дослідник М. Петрунік слушно наголошує на політизованості проблеми сексуального насильства та використанні цієї проблеми 3 метою створення штучної моральної паніки та переключення уваги суспільства від масштабних політичних та соціальних проблем. Так, зазначає М. Петрунік, чимало вкрай небезпечних дій (як умисних, так і необережних), таких, наприклад, як забруднення навколишнього середовища, виробництво продуктів, що містять небезпеку для життя та здоров'я, жорстоке поводження 3 дітьми та керування транспортом у стані сп'яніння, не визначені [належним чином] як небезпечні у кримінальному чи цивільному законодавстві $[10$, c. 1$]$.

Варто наголосити, що із самого початку запровадження законів проти «сексуальних психопатів» у США численні дослідження не продемонстрували будь-якого впливу на вчинення сексуальних злочинів [9, c. 553].

М. Петрунік наголошує на важливій думці, яка безпосередньо стосується нашого дослідження: справжня проблема у більшості західних країн полягає в тому, що громадськість жорстоко обманюється, вважаючи, що закон захищає їх та їхніх дітей від нападу небезпечних сексуа- льних злочинців [11, с. 44-45]. Проте законодавство про dangerous sexual offenders нічого подібного не робить. Водночас нерідко таке законодавство $\epsilon$ знущанням над справедливістю: надання суспільству оманливої небезпеки шляхом ув'язнення супроводжується довічною жахливою деградацією жалюгідної маленької групи соціально та сексуально неадекватних людей.

Проте чи насправді це $є$ проблемою тією мірою, як це представлено внаслідок moral panic та відповідної реакції на неї, - це має бути предметом окремого дослідження на підставі відповідних статистичних та інших даних. Єдине, на чому необхідно наголосити - це аж ніяк не випадковий характер цієї moral panic, адже, як слушно наголошує Д. Сколл, еліти завжди використовують moral panic та створюють нових folk devils, якщо щось загороджує створеній елітами системі соціального контролю [12].

Відповідно, такі слова як «небезпечний», «психопатичний», «схильний до девіації», «має ризики» або «патологічний» стають авторитетними науковими визначеннями. Вони закликають до втручання та розширення повноважень окремих установ та служб, що повністю відображає тенденції «насадження дисципліни» в суспільстві.

При цьому особливе місце посідає культура соціального контролю, яка $\epsilon$ домінуючою культурою у суспільстві XXI століття, що $є$ підгрунтям для соціальних істерик про «загрози та небезпеки злочинності», які, в свою чергу, служать підставою для ухвалення жорстких популістських рішень та реалізації непоміркованих радикальних політик, заснованих на фрустрації, але не справжніх причинах. Між тим, за слушним визначен- 
ням П.-А. Альбрехта, подібні стратегії мають характер «безпрограшних політичних сценаріїв» [13, с. 120].

Тому ми робимо більш ніж особливий наголос на слушності думки видатного італійського кримінолога Д. Мелоссі, що для цілей сучасного соціального контролю репрезентація (representation) злочинності відіграє набагато більшу роль, аніж протидія (repression) злочинності, як це вважалося у 1960-х роках [14, с. 153]. На обгрунтовану думку П. О'Маллі, особливості індивідуалістичного суспільства Постмодерну безпосередньо пов'язані зі страхом, з точки зору якого аналізується каральний поворот у політиці соціального контролю $[15$, c. 183$]$.

Проте, як зазначав видатний американський соціолог І. Гоффман, у сучасному суспільстві існує постійна потреба винайти новий злочин, який би відповідав заздалегідь встановленому для нього покаранню, а сам характер злочинця має бути сформований відповідно до такого злочину [16, с. 334]. Враховуючи, що графи Дракули, вампіри, відьми, дракони, чупакабри, вурдалаки, чугайстери, песиголовці та потерчі вже не можуть справлятися з таким завданням, то для цілей підтримання перманентної moral panic існує потреба постійно створювати нові об'єкти соціального контролю. Тому на порядку денному політики соціального контролю більшості сучасних країн $\epsilon$ відшукання, таврування та ізоляція усіх без винятку sex offenders, що знаходить своє відображення у відповідному законодавстві. Водночас, аналізуючи зазначеному проблематику, необхідно послатися на слушну думку М. Готшалк, що подібні «хвильові» кампанії проте чергових folk devils не $\epsilon$ новим явищем для американського суспільства та системи кримінальної юстиції (проститутки, бутлегери, гангстери, викрадачі дітей, підліткизлочинці, члени організованих злочинних угруповань) [17, с. 42].

Тут ми б хотіли наголосити на важливій думці М. Фуко, яка надає пояснення феномену тотального занурення сексуальної сфери до мереж соціального контролю та дисципліни у другій половині XX - початку XXI століття. Так, М. Фуко ставить слушне в контексті нашого дослідження питання: чому, сексуальність у XIX столітті стала областю такої великої стратегічної значущості? Причому, беремо сміливість додати від себе, - на фоні дедалі більшої сексуальної свободи.

М. Фуко наголошує: 3 одного боку, сексуальність як тілесна поведінка починає підпорядковуватися дисциплінарному контролю над індивідами в формі постійного нагляду. Як приклад дисциплінарного контролю за сексуальністю М. Фуко наводить контроль за мастурбацією, який тотально здійснювався щодо дітей 3 кінця XVIII століття аж до $\mathrm{XX}$ століття в сімейному, шкільному середовищі тощо [18, с. 265]. Так, у США лише у 1968 році мастурбація перестала офіційно розглядатися як психологічне відхилення. Американська медична асоціація оголосила мастурбацію нормальною лише 3 1972 року.

3 іншого боку, наголошує М. Фуко, сексуальність вписується в масштабні біологічні процеси і здійснює на них вплив в силу виробничих функцій, оскільки зазначені біологічні процеси кореспондують не тілу індивіда, а множинній одиничності, яка становить населення. Сексуаль- 
ність - це саме перетин тіл і населення, а тому, наголошує М. Фуко, вона залежить і від дисципліни, і від регуляції [18, с. 265].

Відтак, стає більш зрозумілим, чому середина XX століття стала піком уваги держави до абсолютного контролю над статевими девіантами, а вже на початку XXI століття черга дійшла до тотальної реєстрації будьяких проявів sex offenders та сімейного насильства. Так, у Канаді внаслідок розширення поняття sex offence та широкого дроблення класів sex offenders, кількість sex offenders збільшилася лише за період 1990-1995 років на 40\% [19, с. 167].

У контексті нашого дослідження ми робимо особливий наголос, що у більшості сучасних країн набуває поширення практика внесення небезпечних осіб, здебільшого тих, хто вчинив тяжкі насильницькі та/або sex offences, до спеціальних реєстрів.

Так, станом на середину 2020 року в Шотландії з її населенням у 5,5 млн. осіб було зареєстровано майже 6 тис. sex offenders, що становить 109 осіб на 100 тис. населення.

Проте найбільш яскравим прикладом такого поширення контролю за «секс-девіантами» $є$ США, де станом на 2019 рік було зареєстровано у середньому 500 sex offenders на 100 тис. населення, де лідером 2019 року був штат Орегон 3 показником 688 sex offenders на 100 тис. населення. Станом на січень 2020 року понад 750 тис. осіб у США були зареєстровані як sex offenders та внесені до відповідних реєстрів. Причому докази результативності таких реєстрів $\epsilon$ вельми сумнівними та суперечливими.

У штаті Аляска (США), наприклад, відповідно до Закону «Про реєстрацію злочинців, що вчинили ста- теві злочини», кожен такий злочинець або особа, яка раніше засуджувалася за викрадення дітей, повинна зареєструватися у відповідних державних структурах при перетині кордону штату. Важливою особливістю цього закону є те, що він має зворотну силу та поширюється на осіб цієї категорії, навіть якщо вони вчиняли злочини до набрання цим законом чинності. У справі Smith v. Doe Bepховним Судом США було зазначено, що положення Alaska Sex Offender Registration Act не порушують права та свободи, передбачені законодавством, через те, що його положення $\epsilon$ «не-пунітивними» та становлять «цивільну програму, спрямовану на убезпечення суспільства» [20].

Щодо зворотної сили подібних законів, якими широко характеризується сучасна американська та європейська пенальність, то це становить не лише юридичну проблему з огляду на стандарти прав людини. Це становить проблему, у першу чергу, політичну. Кожного разу, коли йдеться про зворотну силу подібних кримінальних законів, ми можемо шукати ознаки чергового конфлікту між елітами («туристами») та рештою суспільства («бродягами»).

Майже аналогічно подібне питання було вирішено Верховним Судом США у справі Connecticut Department of Public Safety v. Doe: y зазначеному рішенні Суд постановив, що публікація інформації про сексуального злочинця у відповідному реєстрі не порушує належну правову процедуру [21].

Подібними положеннями характеризується законодавство в інших країнах.

Так, у Канаді National Sex Offender Registry запроваджено у 
2004 році. На рівні провінції відповідні заходи вперше було запроваджено в Онтаріо ще 2001 року.

У Великій Британії налічується понад 100 тис. осіб, внесених до спеціального реєстру - Violent and Sex Offender Register. Відповідні закони почали прийматися, починаючи 3 1997 року.

Різні британські заморські території та Коронні володіння також запровадили законодавчі положення щодо реєстрації sex offenders: Бермудські острови - 2001 рік, острів Мен - 2001 рік, Джерсі - 2010 рік, острови Піткерн - 2010 рік, Гібралтар - 2011 рік, Гернсі - 2014 рік.

Республіка Ірландія запровадила відповідне законодавство ще у 2001 році.

Інші європейські країни можуть надати аналогічні приклади. Франція прийняла закон про реєстрацію sex offenders у 2004 році (набрав чинності з 2005 року). Громадяни Франції, які засуджені в іноземних судах за правопорушення, подібні до зареєстрованих у Франції, також повинні реєструватися після повернення до Франції.

Питання створення та ведення французького реєстру sex offenders був предметом справи ЄСПЛ «Gardel v. France» [22].

Так, Національний реєстр осіб, що вчинили статеві або насильницькі злочини, було запроваджено Законом Франції «Про адаптацію системи правосуддя до змін тенденцій злочинності» (2004). Він мав за мету запобігання повторному вчиненню статевих правопорушень, полегшуючи встановлення правопорушників та дозволяючи швидко їх розшукати в будь-який час. Низка перехідних норм викладали детальний механізм унесення до цього реєстру осіб, які вчинили такі правопорушення ще до набрання чинності вище зазначеним законом. Ці положення застосовуються до осіб, які вчинили такі злочини до моменту набрання чинності цим законом. Вони також застосовувалися до осіб, що відбували таке покарання, як позбавлення волі, до набрання чинності цим законом (за клопотанням прокурора).

У цій справі сторони не оспорювали того, що втручання, яке розглядається, відбувалося відповідно до закону і мало законну мету запобігання порушенню правопорядку та вчиненню злочину. Тому ЄСПЛ мав розглянути, чи втручання було необхідним з позиції вимог Конвенції.

Для цілей нашого дослідження важливо наголосити, що ЄСПЛ не піддавав сумніву запобіжну спрямованість такого реєстру, до якого було внесено заявника після його засудження до 15 років позбавлення волі за згвалтування неповнолітньої: метою реєстру було запобігання вчиненню злочинів та, зокрема, боротьба 3 рецидивізмом й полегшення виявлення статевих злочинців.

У цій справі заявника було автоматично внесено до реєстру відповідно до національного закону. Його було належним чином сповіщено про внесення до реєстру та повідомлено про обов'язки, які на нього покладаються.

ЄСПЛ не лише фактично зробив легітимним створення та використання подібних реєстрів як засобу соціального контролю, проте й наголосив, що при внесенні заявника до реєстру статевих злочинців було дотримано справедливий баланс між конкуруючими приватними та публічними інтересами. Держава не ви- 
йшла за межі свободи розсуду в цьому питанні. Відтак, не було порушено статті 8 Конвенції в цій справі.

Крім того, в контексті практики ЄСПЛ необхідно вказати на рішення щодо прийнятності у справі David Adamson v. the United Kingdom [23].

У зазначеній справі заявник вчинив єдине непристойне посягання та був зобов'язаний повідомляти поліцію про свої дані згідно із $\mathrm{Sex}$ Offenders Act 1997. Заявник поскаржився, що занесення його до такого реєстру означає порушення статті 8 Конвенції. ЄСПЛ постановив, що, хоча мало місце втручання у права заявника, передбачені статтею 8 Конвенції, це втручання було необхідним та пропорційним «запобіганню злочинності та захисту прав і свобод інших осіб». ЄСПЛ також постановив, що внесення заявника до відповідного реєстру не становить форму нелюдського поводження, забороненого статтею 3 Конвенції. Також ЄСПЛ постановив, що внесення особи до відвідного реєстру не є покаранням навіть у світлі автономного тлумачення Конвенції (стаття 7 Конвенції). Так, Суд наголосив, що заходи із внесення особи до відповідного реєстру діють абсолютно окремо від звичайних процедур призначення покарання, і вони вимагали від заявника не більше звичайної реєстрації, а тому не можна стверджувати, що заходи, накладені на заявника, становили «покарання» у значенні статті 7 Конвенції.

у справі Massey v. the United Kingdom заявник був засуджений за сексуальні домагання до різних осіб упродовж багатьох років за допомогою телефонних дзвінків та засуджений до 6 років позбавлення волі. Так, заявника було визнано винним у 16 домаганнях та виправдано з 4 епізодами. Водночас на нього було покладено обов'язок реєструватися на невизначний строк. У цій справі ЄСПЛ, посилаючись на справу David Adamson v. the United Kingdom, встановив, що втручання у особисте життя злочинця за статтею 8 було необхідним та пропорційним для попередження злочинів [24].

У справі Robert William Andrew Ibbotson v. the United Kingdom заявник був засуджений згідно із Sex Offenders Act 1997. Заявник стверджував, що перебування в реєстрі є додатковим покаранням, яке накладається після того, як його засудили за злочин, що $\epsilon$ несумісним за статтею 7 Конвенції. Однак Європейська комісія 3 прав людини визнала заяву неприйнятною. Було встановлено, що ці вимоги мають скоріше превентивний, ніж каральний характер - у тому сенсі, що включення до реєстру може допомогти відмовити особу від повторного злочину. Крім того, Комісія наголосила, що хоча недотримання вимог про реєстрацію може становити склад злочину, сама вимога реєстрації не є пунітивною за своєю природою [25].

Україна також не залишилася в стороні від цього позитивістського тренду внаслідок прийняття закону про реєстрацію sex offenders: «Єдиний реєстр осіб, засуджених за злочини проти статевої свободи та статевої недоторканості малолітньої особи автоматизована електронна база даних, створена для забезпечення збирання, зберігання, захисту, обліку, пошуку, узагальнення даних про осіб, які вчинили злочини проти статевої свободи та статевої недоторканості малолітньої особи, у тому числі 
осіб, судимість яких за такі злочини знята або погашена в установленому законом порядку» [26].

Першим австралійським штатом, який прийняв закон про реєстрацію sex offenders, був Новий Південний Уельс у 2000 році. Наразі відповідне законодавство мають усі австралійські штати.

Нова Зеландія запровадила відповідні законодавчі положення, починаючи 32016 року. Подібно до системи у Сполученому Королівстві, тривалість реєстрації варіюється залежно від тяжкості правопорушення та тривалості вироку - від 8 років до довічного терміну.

Підсумовуючи короткий огляд щодо міжнародного досвіду зі створення реєстрів sex offenders, слід зазначити, що 2010 року Парламентська асамблея Ради Європи ухвалила відповідну резолюцію про посилення заходів проти сексуальних злочинців [27]. Аналізуючи цей документ, варто наголосити на його виключно політичній природi, яка багато в чому має популістський характер.

Так, ПАР€ наголошує, що, мовляв, sex offenders вважаються такими, які частіше за інших злочинців вчиняють рецидивні злочини. Тому, як декларує ПАРЄ, необхідність нагляду за sex offenders має бути серйозно сприйнята усіма державами-членами Ради Європи.

Реєстр сексуальних злочинців, відповідно до зазначеної резолюції ПАРЄ, - це інструмент, який передбачає обов'язок засуджених sex offenders повідомляти відповідний орган влади про персональну інформацію, таку як своє ім'я, адреса та дата народження, та негайно інформувати цей орган, якщо зазначена персональна інформація змінюється.
Запис цих повідомлень зазвичай називають реєстром сексуальних злочинців. Щоб такі реєстри були ефективними, вся інформація, що зберігається, повинна бути точною та регулярно оновлюватися.

ПАРЄ робить особливий наголос на тому, що «засуджені sex offenders можуть продовжувати працювати з дітьми та вразливими особами через прогалини в національних або зарубіжних системах. Таким чином, - наголошує ПАРє, - за певних обставин sex offenders можуть знайти роботу в таких сферах, як освіта, в'язнична служба, охорона здоров'я та догляд за дітьми.

Тим самим фактично ПАРЄ перебирало на себе функцію формування єдиного стандарту соціального виключення та локалізації sex offenders.

Цікавим $є$ те, що ПАРє нагадує про рішення ЄСПЛ у справі Gardel v. France, наголошуючи, шо "реєстри сексуальних злочинців (наприклад, у Франції та Великобританії) були визнані Європейським судом 3 прав людини такими, що відповідають нормам Конвенції».

Що $є$ важливим у контексті нашого дослідження, ПАРЄ не підтримує ідею запровадження загальноєвропейського реєстру sex offenders, хоча ідея створення відповідного реєстру під егідою Ради Європи лунала $з 2007$ року. Так само лунали заклики щодо створення подібного реєстру на рівні всього Європейського Союзу (European Sex Offender Database).

Водночас ПАРЄ закликало держави-члени вжити дієвих національних заходів для запобігання сексуальним правопорушенням i, зокрема, inter alia: запровадити комплексні 
правові заходи, спрямовані на контроль та моніторинг руху sex offenders, зокрема подорожей за кордон, а також запровадити систему перевірки та заборони працевлаштування, щоб гарантувати, щоб ті, хто становлять ризик, не змогли б працювати 3 дітьми або вразливими особами.

Отже, як свідчить світова практика, початок нового тисячоліття ознаменувався широким поширенням практики обов'язкової реєстрації sex offenders у відповідних реєстpax, які в деяких країнах можуть бути відкритими для громадськості.

Проте, як вже зазначалося вище, актуалізація убезпечення суспільства від статевих злочинців не $\epsilon$ чимось новим. Так, Г. Шнайдер підкреслює, що сто років тому у США була майже аналогічна moral panic щодо sex offenders, яка зумовила появу позитивістських законів [28]. Проте наразі можна спостерігати, як у законодавстві багатьох сучасних країн офіційно визнано наявність небезпечного типу злочинця, що примушує пригадати Ч. Ломброзо та антропологічну школу. Якщо ще більше замислитися, то на думку спадає інститут особливо небезпечного рецидивіста, який в Україні було ліквідовано як такий, що начебто суперечив правам людини.

Говорячи про кримінологічні аспекти запровадження системи обов'язкової реєстрації sex offenders, необхідно брати до уваги американський досвід оцінки та аналізу результативності подібних заходів соціального контролю.

Так, численні американські дослідження свідчать про відсутність впливу соціально-контрольного ефекту від обов'язкової реєстрації sex offenders на показники злочинності проти статевої свободи.

Подібні висновки було зроблено групою дослідників Чиказького університету, де порівнювалися дані щодо 9 тис. sex offenders, звільнених з місць позбавлення волі у 1994 році. Дослідження дійшло висновків, що близько половини зазначених злочинців були звільнені на постійне місце проживання до штатів, де вони мали юридичний обов'язок зареєструватися та повідомляти про зміну місця проживання, тоді як іншій половині реєструватися не було потрібно. Дослідження виявило незначну різницю у схильності двох груп до вчинення рецидивних злочинів. Більше того, sex offenders, які переїхали до штатів, закони яких не вимагали реєстрації, продемонстрували меншу схильність до рецидивних злочинів. Дослідження дійшло висновку, що sex offenders, які мали обов'язок реєструватися, не продемонстрували нижчих показників рецидиву, як порівняти з тими sex offenders, які не мали такого обов'язку. Крім того, дослідження дійшло висновку, що володіння правоохоронними органами інформацією про місце проживання sex offenders не впливає на показники рецидивної злочинності таких злочинців [29, с. 207-239].

Інше дослідження щодо запобіжного впливу заборон на проживання sex offenders у визначених органами влади місцях виявило низку негативних наслідків, включаючи втрату житла, втрату соціальної підтримки та фінансові труднощі, які можуть насправді збільшити кількість рецидивних злочинів. Крім того, обмеження на проживання призводили до переміщення та кластери- 
зації sex offenders в інших районах, зокрема сільських [30].

Ще одне дослідження було сфокусовано на аналізі традиційних превентивних заходів щодо sex offenders у 10 американських штатах. За результатами дослідження було виявило, що статистично значуще скорочення числа випадків зґвалтування відбулося після впровадження превентивних заходів у 3 з 10 штатів. У шести штатах суттєвих змін не спостерігалося, а в одному штаті взагалі спостерігалося статистично значне збільшення кількості sex offences. Автори дійшли висновку, що традиційні превентивні заходи, вироблені у рамках moral panic перед sex offenders, мають майже нульовий вплив на рівень зареєстрованих згвалтувань [31].

На додаток, американські вчені загострюють увагу на тому, що саме реєстри сексуальних злочинців, що містять їхні імена, адреси та фотогра$\phi і i і,, \epsilon$ відкритими для усіх бажаючих. Люди цікавляться такою інформацією і платять більше, щоб уникнути проживання поруч із зареєстрованими сексуальними злочинцями. Так, як підкреслює А. Аган, будинки, що перебувають поруч із місцем реєстрації сексуального злочинця, продаються приблизно на 5,5 тис. доларів дешевше, ніж аналогічні будинки, що знаходяться далеко від місць проживання сексуальних злочинців [29].

Отже, йдеться про те, що система кримінальної юстиції стає дедалі більш схожою на елементарний соціальний фільтр, наслідком застосування якого $€$ ще більше сегрегація, соціальне розшарування та дискримінація, що класична школа кримінального права вперто не помічає.

Висновки. Підсумовуючи викладене вище, можна наголосити на такому. На перший погляд, $\mathrm{y}$ XXI столітті говорити про друге життя вчення Ч. Ломброзо та інших біологічних позитивістів $є$ спрощенням проблематики. Проте, проаналізувавши наслідки кризи покарання та зміну сутності в'язниці, обумовлені глобалізаційними впливами, можна впевнено сказати: позитивістська філософія дедалі більше відображає реальний стан кримінальної та пенітенціарної політики сучасних національних держав.

Зазначена проблема стосується іншої - проблеми вищого рівня. Так, актуалізація соціального контролю над sex offenders віддзеркалює перехід від «покарань» до «заходів безпеки», що означає перехід від класичного «виконання покарань» до позитивістського «менеджменту у сфері убезпечення суспільства».

Саме ця проблема відображена у поглядах П.-А. Альбрехта, де вчений обгрунтовано доводить, що розширення вимог кримінального права вступає в конфлікт 3 основним принципом вини. В цілому невдала індивідуалізація кримінальної відповідальності не здатна впоратися зі структурними процесами світової інтеграції. Як наслідок, [класичне] кримінальне право не підходить на роль засобу управління [13, с. 77-78]. Невипадково, гадаємо, П.-А.Альбрехт аналізує проблему «від'єднання індивідуальної відповідальності», що характеризує кримінальне право Європи, та вказує на домінування категорії «ризиків» у сучасних індустріалізованих суспільствах. Відтак, йдеться про європейське право ризиків на відміну від європейського права свободи.

Подальша трансформація політики соціального контролю у XXI столітті пов'язана 3 наступними 
моментами: 1) переглядом цільового призначення ув'язнення як покарання; 2) одночасним намаганням додати до пунітивного соціальноконтрольного репертуару як можна більше альтернативних покарань (покарань у громаді); 3) зміною характеру альтернативних покарань (покарань у громаді), i, як наслідок, 4) зміною цілей інституту кримінального покарання, які впродовж тривалого часу мали статус «традиційних».

Крім того, аналізуючи подану вище тезу, ми одночасно повинні надати їй подальшого розвитку в силу того, що кримінальне право ризиків, власне, вже не є кримінальним правом, адже класичного інструментарію не вистачає, щоб контролювати ризики, регулювати ризики та карати за надмірне демонстрування ризиків.

Тому кримінальне право ризиків широко почало використовувати навіть арсенал некримінальних заходів, які подаються як «непунітивні цивільні заходи».

\section{Список використаних джерел}

1. Taylor I., Walton P., Yong J. The New Criminology; For a Social Theory of Deviance. London-Boston : Routledge \& Kenan Paul, 1973. 325 p.

2. Дриль Д. Преступность и преступники. Учение о преступности и мерах борьбы с нею. Москва, 2006.

3. Вульферт А. Антрополого-позитивная школа уголовного права в Италии. Критическое исследование. Москва : Типография В.В. Исленьева, 1887. 509 с.

4. Ferri E. Criminal Sociology. London: Fisher Unwin, 1895. 284 p.

5. Dubber M. 'Criminal Justice Process and War on Crime', in The Blackwell Companions to Sociology, C. Sumner (ed.), Blackwell Publishing Ltd, 2004.

6. Van der Wolf M. Legal Control on Social Control of Sex Offenders in the Community: A European Comparative and Human Rights Perspective. Erasmus Law Review, 2016. Vol. 9, № 2 .

7. Chenier E. Stranger in Our Midst: Male Sexual «Deviance» in Postwar Ontario. A thesis submitted to the Department of History in conformity with the requirements for the degree of Doctor of Philosophy. Kingston: Queen's University, 2001. 418 p.

8. Оруєлл Д. 1984; Скотный двор. Москва : АСТ : Астрель, 2011. 361 с.

9. Sutherland E. The Sexual Psychopath Laws. Journal of Criminal Law and Criminology, 1950. Volume 40, Issue 5, Article 1.

10. Petrunik M. The Makings of Dangerous Offenders: The Origins' Diffusion and Use of Legislation for Dangerous Offenders in Europe and North America. Ottawa: Ministry of the Solicitor General, Research' Division, № 1984-74. 109 p.

11. Greenland C. Dangerous sexual offenders in Canada. Canadian Journal of Criminology and Corrections, Jan. 1972. 14.

12. Skoll G. Social Theory of Fear: Terror, Torture, and Death in a Post-Capitalist World. Basingstoke: Palgrave Macmillan, 2010.

13. Альбрехт П.-А. Забытая свобода. Принципы уголовного права в европейской дискуссии о безопасности. Издание 2-е. Харьков: Право, 2012. 184 с.

14. Melossi D. Controlling Crime, Controlling Society: Thinking about Crime in Europe and America. Malden, MA: Polity, 2008.

15. O'Malley P. Penal Policies and Contemporary Politics, in C. Sumner (ed.), The Blackwell Companions to Sociology. Blackwell Publishing Ltd, 2004. 
16. Goffman E. Asylums. Harmondsworth: Penguin, 1968.

17. Gottschalk M. The Prison and the Gallows: The Politics of Mass Incarceration in America. New York: University of Pennsylvania, 2006. 486 p.

18. Фуко М. Нужно защищать общество. Курс лекций, прочитанных в Коллеж де Франс в 1975-1976 учебном году. СПб.: 2005. 312 с.

19. Duguid S. Can Prisons Work? The Prisoner as Object and Subject in Modern Corrections. Toronto: University of Toronto Press. $298 \mathrm{p}$.

20. Smith v. Doe, 538 U.S. 84 (2003). URL: http://caselaw.lp.findlaw.com

21. Connecticut Department of Public Safety v. Doe (01-1231) 538 U.S. 1 (2003) 271 F.3d 38. URL: www.law.cornell.edu/supct/html/01-1231.ZS.html

22. «Gardel v. France», application № 16428/05, Judgment 17.12.2009.

23. «David Adamson v. the UK» (dec.), application № 42293/98, decision 26.01.1999.

24. «Massey v. the UK», application № 14399/02, judgment 16.11.2004.

25. «Robert William Andrew Ibbotson v. the UK» (dec.), application № 40146/986 decision 21.10.1998.

26. Закон України «Про внесення змін до деяких законодавчих актів України щодо впровадження Єдиного реєстру осіб, засуджених за злочини проти статевої свободи та статевої недоторканості малолітньої особи, та посилення відповідальності за злочини, вчинені проти статевої свободи та статевої недоторканості малолітньої особи». Відомості Верховної Ради (ВВР). 2020. № 27, ст.175 URL: https://zakon.rada.gov.ua.

27. Reinforcing measures against sex offenders. Resolution of the Parliamentary Assembly 1733 (2010) Final version. Text adopted by the Standing Committee, acting on behalf of the Assembly, on 21 May 2010 (see Doc. 12243, report of the Committee on Legal Affairs and Human Rights, rapporteur: Mrs de Pourbaix-Lundin). URL: http://assembly.coe.int

28. Шнайдер Г. Криминология. Москва: Издательская группа «Прогресс» - «Универс», 1994. 505 c.

29. Agan A. Sex Offender Registries: Fear without Function. Journal of Law and Economics. 2011. 54 (1).

30. Lobanov-Rostovsky C. 'Sex Offender Management Strategies', in Sex Offender Management Assessment and Planning Initiative. Washington, DC: U.S. Department of Justice, Office of Justice Programs Office of Sex Offender Sentencing, Monitoring, Apprehending, Registering, and Tracking, 2017.338 p.

31. Walker J., Maddan S., Vasquez B., VanHouten A., Ervin-McLarty The Influence of Sex Offender Registration and Notification Laws in the United States. Little Rock, AR: Arkansas Crime Information Center, 2006. 19 p.

\section{References}

Taylor, I., Walton, P., Yong, J. (1973). The New Criminology; For a Social Theory of Deviance. London-Boston : Routledge \& Kenan Paul.

Dril D. (2006). Prestupnost i prestupniki. Uchenie o prestupnosti i merah borby s neyu. Moskva [in Russian].

Vulfert, A. (1887). Antropologo-pozitivnaya shkola ugolovnogo prava v Italii. Kriticheskoe issledovanie. Moskva: Tipografiya V.V. Isleneva [in Russian].

Ferri, E. (1895). Criminal Sociology. London: Fisher Unwin.

Dubber, M. (2004). 'Criminal Justice Process and War on Crime', in The Blackwell Companions to Sociology, C. Sumner (ed.), Blackwell Publishing Ltd.

Van der Wolf, M. (2016). Legal Control on Social Control of Sex Offenders in the Community: A European Comparative and Human Rights Perspective. Erasmus Law Review, 9, 2. 
Chenier, E. (2001). Stranger in Our Midst: Male Sexual «Deviance» in Postwar Ontario. A thesis submitted to the Department of History in conformity with the requirements for the degree of Doctor of Philosophy. Kingston: Queen's University.

Oruyell, D. (1984). Skotnyj dvor. Moskva: AST : Astrel [in Russian].

Sutherland E. (1950). The Sexual Psychopath Laws. Journal of Criminal Law and Criminology, 40, 5, 1 .

Petrunik, M. (1984). The Makings of Dangerous Offenders: The Origins' Diffusion and Use of Legislation for Dangerous Offenders in Europe and North America. Ottawa: Ministry of the Solicitor General, Research' Division, 74, 109.

Greenland C. (1972). Dangerous sexual offenders in Canada. Canadian Journal of Criminology and Corrections, Jan, 14.

Skoll, G. (2010). Social Theory of Fear: Terror, Torture, and Death in a Post-Capitalist World. Basingstoke: Palgrave Macmillan.

Albreht, P.-A. (2012). Zabytaya svoboda. Principy ugolovnogo prava v evropejskoj diskussii o bezopasnosti. Izdanie 2-e. Harkov: Pravo [in Russian].

Melossi, D. (2008). Controlling Crime, Controlling Society: Thinking about Crime in Europe and America. Malden, MA: Polity.

O’Malley, P. (2004). Penal Policies and Contemporary Politics, in C. Sumner (ed.), The Blackwell Companions to Sociology. Blackwell Publishing Ltd.

Goffman, E. (1968). Asylums. Harmondsworth: Penguin.

Gottschalk, M. (2006). The Prison and the Gallows: The Politics of Mass Incarceration in America. New York: University of Pennsylvania.

Fuko, M. (2005). Nuzhno zashishat obshestvo. Kurs lekcij, prochitannyh v Kollezh de Frans v 1975-1976 uchebnom godu. SPb.

Duguid, S. (2000). Can Prisons Work? The Prisoner as Object and Subject in Modern Corrections. Toronto: University of Toronto Press.

Shnajder, G. (1994). Kriminologiya. Moskva: Izdatelskaya gruppa «Progress» - «Univers» [in Russian].

Agan A. (2011). Sex Offender Registries: Fear without Function. Journal of Law and Economics, 54 (1).

Lobanov-Rostovsky, C. (2017). 'Sex Offender Management Strategies', in Sex Offender Management Assessment and Planning Initiative. Washington, DC: U.S. Department of Justice, Office of Justice Programs Office of Sex Offender Sentencing, Monitoring, Apprehending, Registering, and Tracking.

Walker, J., Maddan, S., Vasquez, B., VanHouten, A., Ervin-McLarty (2006). The Influence of Sex Offender Registration and Notification Laws in the United States. Little Rock, AR: Arkansas Crime Information Center.

D. Yagunov, Meritorious Lawyer of Ukraine, PhD in Public Administration, Associate Professor, MSSc in Criminal Justice

e-mail: d.yagunov@gmail.com; ORCID: 0000-0002-2822-2268

\section{Sex offenders in the social control policy: concerning the issue of re-actualization of the concept of a dangerous individual}

The article is focused on the study of current trends of social control policy in Western countries aimed at protecting society against sexual violence. The article contains an analysis of political transformations - from «criminal law of freedom» to «criminal law of risks». 
A special stress is made on the practices of the European Court of Human Rights concerning application of the Article 8 of the European Convention of Human Rights for issues of registering of sex offenders («David Adamson v. the UK» (dec.), «Robert William Andrew Ibbotson v. the UK» (dec.), Gardel v. France»). The most important US judicial practices are also taken into consideration ( $S$ Smith v. Doe», «Connecticut Department of Public Safety v. Doe»).

The paper contains an analysis of legislation of Western states focused on the issues of registering of sex offenders.

This paper stresses on actualization of social control over sex offenders, which reflects the transition from "punishment" to "security measures", which, in its turn, means the transition from the classic "execution of punishment" to positivist "management in the area of social security".

The paper stresses that further transformation of social control policy in the XXI century is connected with the following moments: 1) revision of the purpose of imprisonment as a punishment; 2) simultaneous efforts to add as many alternative punishments as possible to the punitive social control repertoire (community punishments); 3 ) changing the nature of alternative punishments (community punishments), and, as a consequence, 4) changing the goals of criminal punishment, which for a long time had the status of "traditional". In addition, analyzing the above thesis, we must at the same time give it further development due to the fact that "criminal law of risks", in fact, is no longer a criminal law, because the classical tools are not enough to control risks, regulate risks and punish excessive risk. Therefore, "criminal law of risks" has begun to be widely used even in the arsenal of noncriminal measures, which are presented as "non-punitive civil measures".

Keywords: social control policy; positivist school; dangerous individual; sexual violence; penitentiary system; safer society. 